\title{
THE EFFECT OF GENDER IN THE RELATIONSHIP OF CAREER DEVELOPMENT AND JOB SATISFACTION FOR FEMALE EMPLOYEES
}

\author{
Ergün KARA ${ }^{1}$
}

\begin{abstract}
Despite the fact that males and females have the same working conditions in almost whole sectors in the World, it is seen that generally males work in especially administrative positions which have strategical importance. Similarly, it is seen that in health sector which is one of the most important sectors of working life in our country, females are employed less in administrative level. Therefore, with this study it was tried to determine whether gender has a mediating role in the relationship of career development and job satisfaction for females working in health sector or not. Population is composed of public and private hospitals in Osmaniye province, 200 employees working in these hospitals were determined as samples and said employees were exposed to questionnaires. In the study, correlation analysis was made in order to determine the effect of gender on career and regression analysis of structural equation modeling was made in order to test the mediating effect. According to the result of the research, it was found that there was a negative relationship between gender and career and a positive effect of gender in the relationship of career development and job satisfaction for females.
\end{abstract}

Keywords: Female Employee, Career Development, Health Sector

JEL Classification: J21, J71, M54

\section{KADIN ÇALIŞANLARDA KARIYER GELIŞiMi VE iş TATMINi iLişKISINDE CINSIYETIN ETKisi}

öz

Dünyadaki hemen hemen bütün sektörlerde kadınlar ve erkeler eşit çalışma şartlara sahip olmalarına rağmen, özellikle stratejik öneme sahip yönetim kademelerinde genellikle erkeklerin görev yaptığı görülmektedir. Benzer şekilde Ülkemizde de çalışma hayatının en önemli sektörlerinden birisini oluşturan sağlık sektöründe çalışan kadınlara yönetim kademesinde çok az görev verildiği görülmektedir. Bu nedenle, bu araştırmayla sağlık sektöründe çalışan kadınların kariyer gelişimleri ve iş tatmini ilişkisinde cinsiyetin aracılık rolünün bulunup bulunmadığı tespit edilmeye çalışılıştır. Araştırmanın evrenini Osmaniye ilindeki kamu ve özel hastaneler oluşturmakta olup, bu hastanelerde görev yapan 200 personel örneklem olarak belirlenmiş ve söz konusu personele anket çalışması yapıımıştır. Çalışmada cinsiyetin kariyer üzerindeki etkisini tespit etmek için korelasyon, aracılık etkisini test etmek içinse yapısal eşitlik modellemesi regresyon analizi yapılmıştır. Araştırma sonucuna göre cinsiyet ve kariyer arasında negatif bir ilişki bulunmakta ve kadınların kariyer gelişimi iş tatmini ilişkisinde cinsiyetin anlamlı pozitif bir etkisi söz konusudur.

Anahtar Kelimeler: Kadın Çalışan, Kariyer Gelişimi, Sağlık Sektörü

JEL SInıflandırması: J21, J71, M54

${ }^{1}$ Asst. Prof. Dr., Osmaniye Korkut Ata University, ergunkara@osmaniye.edu.tr ORCiD: 0000-0002-7815-1111 


\section{Introduction}

For centuries, the society added several roles such as wife, mother and housewife to female. According to these roles, females became dependent to males by keeping away from production, moreover, were pushed to "social insignificance" because the things they made did not have an economic value. This situation limited the entrance of females to business life and choice of profession, obstructed the career advancement. Today's rapid economic, social and technological developments caused the participation of females to business life more and actively. The increase of the participation of females into business life is important for both themselves and their families and accordingly for the development of the society (Özçelik, 2017: 50).

Despite the fact that female population in the world composes almost the half of the society, the reason why females cannot be involved in administrative positions in business life in the same level with males was determined by the roles for females provided by societies most of the time. At the same time, the fact that job descriptions and working conditions were determined mainly for males within societies caused the fact that females were pushed into background and cannot be involved in the top brass. As a matter of the traditional roles expected from females, psychologically double bind for females between their families and career made career development difficult for females. Even though there are provisions which present equal opportunities for whole male\&female employees in all fields of business life without any gender gap in laws of several developed countries and international documents, females are exposed to invisible obstructions which cannot be explained explicitly in business life. The fact that females exposed to such informal and undiscoverable substantially obstructions is called "Glass Ceiling Syndrome" in administrative literature. Even if glass ceiling syndrome seems to be a situation that only females are obliged to live, today it cannot be limited with females only, it is stated that ethnic minorities and males can live glass ceiling syndrome too in their career development phases (Korkmaz, 2014: 2).

This study is for measuring the effect of gender in the relationship of career development and job satisfaction for female employees. Additionally, researches about this subject and such subjects were examined. In the study, it was tried to reveal obstructions in the involvement of females for executive positions by evaluating the theoretical information and findings as a result of the application.

\section{Female in Business Life}

The conditions of females within business life is a subject of multi-dimensional public health which should be examined in relation to economic, social, biological, cultural and such several factors. Despite the fact that females worked in whole levels of the production throughout history, they are still evaluated as disadvantaged individuals. Participation of females into work power is accepted to be an important factor of sustainable development, social development and social welfare. When the reasons of the problems that females come across in work environment, gender originated professional discrimination is in the first place. When females worked in a happy job in which they get their money's worth, they contribute to family budget and besides they spend most of their income and time to their children. Accordingly, this enables the next generations to be healthier and more educated (Gül et al., 2014: 169).

According to researches conducted, it was seen that female jobs were generally teaching, nursing, cleaning services and baby-sitting and etc. which were the extensions of being housewife and mother and most of these jobs which were generally made by females were underestimated. Despite the fact that most of the time, the jobs made by females require more talent and experience than the jobs of males who get higher wages, they get lower wages, because these jobs are seen to be female works (Palaz, 2003,99). 


\subsection{Situation of Female Employees in the World and Turkey}

When the situation of females in business life in the world is investigated historically, the notion that females are obliged to live under the hegemony of males and look after their families, houses and children from past to present is dominant. Passing to permanent settlement with agriculture did not become enough for females to get rid of secondary status in social and economic life. Together with the sectoral transformation liven in developed country economies beginning from the year of 1950, females started to work in service areas such as hospitals, public institutions and etc. free trade emerged cheap labor which is the residues of multinational corporations in 1970s. Especially females were affected from this situations and they were forced to work for lower wages (Kılınç, 2015: 126).

In textile sector which had a great effect in the industrialization process in the whole western economics in the 19th century, predominantly female workers were employed. Females who worked due to economic obligations in this period were exposed to intense exploitation. At the end of the century, in other industrial sectors such as metallurgy, car, chemistry etc. not much female work power was used. On the other hand, it was observed that the ratio of participating in the work power for females became to a decreasing tendency with the development and maturation of the industry. Because, the development of social welfare causes the extension of education durations and retirement ages and increase in free time consumption. According to a research including the age range of $20-64$ in 2015 , average male employment ratio is $75,9 \%$ and female employment ratio is $64,3 \%$ in $28 \mathrm{EU}$ countries (Sağlam, 2017: 5).

Turkey had made several legal arrangements for the benefit of females in order to eliminate the gender gap in the EU harmonization process. Foremost among these are arrangements made for the benefit of females by removing the items pertaining to gender gap in Civil Code entered into force in 2002, amendment in the 10th item of the Constitution in 2004 and Labor Code no. 4857 and Social Security Law no. 5510 (Korkmaz and Korkut, 2012: 60). When the Tenth Development Plan including the period of 2014-2018 is examined, it was stated that participating to labor force and increasing the employment for initially youth and females, decreasing unemployment and preventing informal employment, increasing the quality of labor force and decreasing the tangible employment maintained their importance (Önder, 2013: 45).

Table 1: Fundamental Work Power Indications (2016-2017)

\begin{tabular}{|c|c|c|c|c|c|c|}
\hline & \multicolumn{2}{|c|}{ TOTAL } & \multicolumn{2}{|c|}{ MALE } & \multicolumn{2}{|c|}{ FEMALE } \\
\hline & 2016 & 2017 & 2016 & 2017 & 2016 & 2017 \\
\hline (Age of 15 and above) & \multicolumn{6}{|c|}{ (THOUSANDS) } \\
\hline Population & 58.720 & 59.894 & 29.031 & 29.649 & 29.689 & 30.244 \\
\hline Work power & 30.535 & 31.643 & 20.899 & 21.484 & 9.637 & 10.159 \\
\hline Employment & 27.205 & 28.189 & 18.893 & 19.460 & 8.312 & 8.729 \\
\hline Agriculture & 5.305 & 5.464 & 2.920 & 2.993 & 2.384 & 2.471 \\
\hline Non-Agriculture & 21.901 & 22.724 & 15.973 & 16.467 & 5.928 & 6.258 \\
\hline Unemployed & 3.330 & 3.454 & 2.006 & 2.024 & 1.324 & 1.431 \\
\hline Not in labor force & 28.185 & 28.251 & 8.133 & 8.166 & 20.052 & 20.085 \\
\hline \multicolumn{7}{|c|}{$(\%)$} \\
\hline Labor force participation rate & 52,0 & 52,8 & 72,0 & 72,5 & 32,5 & 33,6 \\
\hline Employment rate & 46,3 & 47,1 & 65,1 & 65,6 & 28,0 & 28,9 \\
\hline Unemployment rate & 10,9 & 10,9 & 9,6 & 9,4 & 13,7 & 14,1 \\
\hline Non-agricultural unemployment rate & 13,0 & 13,0 & 10,9 & 10,7 & 18,1 & 18,5 \\
\hline \multicolumn{7}{|l|}{ 15-64 Age Group } \\
\hline Labor force participation rate & 57,0 & 58,0 & 77,6 & 78,2 & 36,2 & 37,6 \\
\hline Employment rate & 50,6 & 51,5 & 70,0 & 70,7 & 31,2 & 32,2 \\
\hline Unemployment rate & 11,1 & 11,1 & 9,8 & 9,6 & 14,0 & 14,4 \\
\hline Non-agricultural unemployment rate & 13,0 & 13,1 & 10,9 & 10,8 & 18,2 & 18,6 \\
\hline
\end{tabular}




\section{What is Career?}

Career management and performance evaluation systems for the organizations which are used in order to achieve their goals and increase their productivity are the periods under the human resources management and they are closely associated with whole other human resources management functions. Developments in technological fields, changes in the qualities of the works and the requirement to plan the future necessities of the organizations revived the concepts of corporate career development and performance evaluation. Career is the development and gaining experience and abilities for individuals throughout their work lives. Career is directly related with the individual and organizational goals and is a process which is connected with work experience and activities that individuals will live throughout their lives and can partially control (Tunçer, 2012: 215).

Embracing the concept of career as using the positions of the individuals' jobs in sequence throughout their individual lifetimes brings the existence of three fundamental dimensions to the agenda in career fact. These are individual, job and positions. Due to the existence of job and position necessitates an organization, individual and organization come together correlatively throughout a career. In other words, career concept has a two dimensional importance as individual and organization substantially. The first dimension will be formed in the personality of the individuals who plan their careers undoubtedly. Individuals should understand their position within professional life and their organizations and determine where and how they want to see themselves in the future. This situation which can be called as individual orientations is described as the fact of "self-fulfillment". In the direction of this motivation, individuals will need to develop their careers, improve and advance. In the other dimension, the organization should have a good communication with the individuals where they want to reach, how and in what way they will reach there by considering its own goal and provide necessary consultancy services to the individuals and undertake the responsibility in the way of easing the their advancements (Şimşek and Öge, 2007 : 260).

\subsection{Career Planning}

Career planning is developing the talents, knowledge, abilities and motivations of the employees and planning the advancement and improvement within the organization (Tüz 2003: 171). In other words, career planning defines the period of problem solving and decision taking which aim to from an appropriate relationship between requirements \& values and work experience \& opportunities of employees. This enables the happiness of the employees and increase in the efficiency in their duties. It has the conditions of estimating the future, knowing what is expected, determining the goals accordingly, keeping the motivation high, employees who devote themselves to work (Barutçugil, 2004: 329).

Today, it is an important detail that career is in the responsibility of the individual. Besides, organizations should support the individual about the subject (Aytaç, 2005: 233). Individuals should think of how the advancements will be and how to get out of the crowds in a world that securities of organizations gradually decreased or totally disappeared. Accordingly, if employees can know where they are within professional life, what they can do and what they can do in the future, they will understand where they will go, what they will need to do in order to reach their goals. These opportunities will be provided to individuals by career planning (Anafarta, 2008: 3).

\subsection{Career Obstructions in Female Employees}

As we know, gainful occupation enables economic, social security and effective participation into society and accordingly contribute the increase of social status for females. However, existing individual, family, organizational and social factors, especially the attitude of society towards gender roles and female employment continue to obstruct the development of females (Aytaç, 2001: 204). 
Even if there are differences changing from country to country, traditional roles of females are limited with their houses, children and families, getting to certain positions were restricted to several obstacles in business life. It was expected from females to undertake the social roles of mother and wife, their professional success and careers stayed in the background (Aytaç, 1999: 27).

\subsubsection{Gender Gap}

Gender gap arises when it was taken into consideration to gender, that is to say an attributed property rather than decisions pertaining to employees, qualities of the individuals or job performances (Gutek et al., 1996: 791). In business life, mostly females are exposed to gender gap. For instance, roles and responsibilities of females within family life limit the opportunity to promote in their professions. This tendency revealed the concept of "glass ceiling" which is basis of discrimination against women. The obstacles which stops the advancements of females towards executive positions are called as "glass ceiling" (Aytaç et al., 2002: 7-49). The reality of glass ceiling was verified by the researches.

\subsubsection{Glass Ceiling Syndrome}

The concept of "Glass Ceiling" was used in the news of Wall Street Journal under the subject of "Women in Business Life" by Hymovitz and Schellhard in 1986. According to this, glass ceiling was defined as the "obstacles that females met who desired to be in executive positions and struggled for this goal in public and companies, educational institutions or non-profit organizations" (Lockwood, 2004).

Glass ceiling describes the invisible and impassable obstacles between females and executives and inhibit their advancement without considering their success and competence (Aytaç, 2001: 2728).

\subsubsection{Traditional Organizational Culture}

For females to take equal opportunities in career possibilities changes according to organizational culture. While in some organizations conditions are the same, in some other organizations females have to make more efforts to establish themselves (Akın, 2006). According to this, it is stated that "male focused" organizational cultures which are characterized with authority, autonomous, authocratic leadership style and top-down communicational form are important obstacles in the advancement of females. It is stated that advancement of females within organization are related with human centric, dependent to performance evaluation, including low power distance and based on gender equality (Ergenel and Akçamete, 2004: 84).

Table 2: Positioning Females within Male-Dominant Organizational Culture

\begin{tabular}{|c|c|c|c|}
\hline & \multicolumn{3}{|c|}{ POSITIONING FEMALES } \\
\hline Position of Male & Accepted & Opposed & Established \\
\hline Friendly & Visitor (Guest) & $\begin{array}{c}\text { Summer house va- } \\
\text { cationist }\end{array}$ & New arrival \\
\hline Unfriendly & Marginal & Mole & Uninvited guest \\
\hline
\end{tabular}

Resource: Karaca, 2007.

According to the model, glass ceiling and the existence of glass ceilings towards females are more present in "guest" metaphor than metaphors in Table 2. Because in this metaphor, the position of the female within the organization is assimilated to the position of the guest. As guest is seated to the head corner, behaved politely but is not allowed to wash the dishes and enter the whole rooms in the house, the females within the organization are exposed to similar polite but invisible limitations (Karaca, 2007: 58). 


\section{Job Satisfaction}

Employee satisfaction or job satisfaction attract the attention as a subject which is frequently examined under the title of organizational behavior within administrative area. Job satisfaction emerges with different definitions in job satisfaction. Vroom (1964) defines the job satisfaction as emotional reactions by employees in several periods of the job. Locke (1976) defines the job satisfaction as positive experiences taken from job, positive values given to job and returned pleasure emotion. While Spector (1997) explains job satisfaction as the emotions for workplace and held duties of the employees in the low end, Lu et al. (2005) explain job satisfaction as award, promotion or such motivational factors for employees from their workplace in return for their labor.

Job satisfaction is accepted as a degree of content of employees from their jobs and it is an important concept in order to determine the reactions of employees towards their jobs in organizational studies. The first systematical studies towards job satisfaction date back to 1930s (Agho et al., 1993: 1007). The most important two factors generally emerge in the describing the job satisfaction is the expectations and gains of employees. In other words, the most important scale which decreases or increases the job satisfaction of employees is awards or maybe punishments taken from the workplace. If gains are equal to or higher that the expectations of the employees, job satisfaction is present definitely. However, otherwise job dissatisfaction will emerge.

\section{Literature Search}

As a result of local and foreign literature searches directed to the study, the effect of gender in the relationship of career development and job satisfaction for female employees has critical value in terms of females. In this section of the study, it was tried to narrate the scientific studies within the literature pertaining to the relationship between career development and job satisfaction within the accessible scale. Within this scope, findings taken from both national and international studies were summarized and narrated in the following.

Karaca and İraz (2007), conducted a research on female and male executives working in public and private bank branches in Konya in order to examine the factors which are qualifies as obstruction and glass ceiling for female employees to reach executive positions under a frame and support within an application study. As a result of the study, it was concluded that there were several different reasons which explained the career obstructions of females and several suggestions were made.

Acuner (2019), conducted a study in order to determine the problems of female employees in their career development process within the public sector in the province of Trabzon. As a result of the research; it was concluded that female employees overcame several responsibilities, had problems in social gender stereotypes, organizational culture, human resources applications, gender gap, self-obstructions, mentor deficiency and female executive perceptions and solution suggestions were developed directed to these problems.

Anafarta, Sarvan and Yapıcı (2008), conducted a study in order to examine the perceptions of career obstructions and existence of glass ceiling for 151 female executives in accommodation establishments in and around Antalya. As a result of the research, it was concluded that female executives working in accommodation establishments have the perception of more discrimination in terms of wage, education and promotion opportunities, moreover female executives felt the perception of glass ceiling more because they have to struggle between job and family roles and do not have a guide.

Inandı and Tunç (2012), conducted a study in order to determine the relationship between career obstructions and job satisfaction levels and regression level for total 1070 female teachers who work in primary schools in city centers of 21 provinces. As a result of the research, it was determined that females could not reveal a strong relationship between career obstructions and 
job satisfaction levels and female teachers had limited effect on career obstructions, job satisfaction subdimensions.

Soysal (2010), conducted a study in order to review a contextual frame for obstructions and opportunities of female entrepreneurs within the perspective of Turkey. As a result of the research, it was concluded that female entrepreneurs had important contributions in the development of their countries' economies and job creation by creating important profit and opportunities in economic and social lives.

Uygun and Öğ̈̈ (2011), conducted a research in establishments in the province of Konya in order to determine whether there was a relationship between factors such as administrative properties and management style in organizational culture and demographical properties and career developments of female employees or not. As a result of the research, it was determined that there was a relationship between management style and career development, however there was not a relationship between demographical properties and career developments of female employees.

In the said literature review, it is seen that there is a close relationship between career development and job satisfaction. Therefore, in the study it was examined that whether there was a mediating effect of gender in the relationship of career development and job satisfaction for female employees or not and its degree of influence, hypotheses were formed accordingly.

$\mathbf{H}_{0}$ : Gender does not have a mediating role in the relationship of career development and job satisfaction for female employees.

$\mathbf{H}_{1}$ : Gender has a mediating role in the relationship of career development and job satisfaction for female employees.

\section{Methodology of the Reseach}

\subsection{Research Objective and Method}

The objective of this study is to measure the effect of gender in the relationship of career planning and job satisfaction for female employees. Said study was conducted for employees working in public and private hospitals in the province of Osmaniye. In the research, first of all the reliability of the scales were tested, correlation analysis was made for the relationship among variables and good fit values among variables were observed via confirmatory factor analysis. At the final period of the study, it was tried to determine the effect of gender in the relationship of career planning and job satisfaction via path analysis method of structural equation modeling.

\subsection{Research Scope and Scales}

Population of the research is composed of 680 health sector employees working in public and private hospitals in the province of Osmaniye. Sample of this research conducted on health sector is composed of public and private hospitals in the province of Osmaniye. Questionnaires were applied on 325 health sector employees selected as sample in this way and 200 gained questionnaires were used as data set in the research. In the first section of the questionnaire, questions pertaining to demographical data; in the second section "career planning Scale" with 25 items developed by Rottinghaus, Day and Borgen (2005) ; in the third section "Job Satisfaction Scale" with 20 questions developed by Weiss, Dawis, England and Lofquist (1967) and in the final section of the questionnaire "Scale of Social Gender Roles Manner" with 9 items developed by Zeyneloğlu and Terzioğlu (2011) were used. 


\subsection{Evaluation of Findings}

Table 3: Information of Participant

\begin{tabular}{|c|c|c|c|c|c|}
\hline Gender & Frequency & \% & Position held & Frequency & $\%$ \\
\hline Female & 108 & 54 & Executive & 23 & 11,5 \\
\hline Male & 92 & 46 & Employee & 177 & 88,5 \\
\hline Age & & & Sectoral experience & & \\
\hline $18-25$ & 49 & 24,5 & $1-5$ Years & 53 & 26,5 \\
\hline $26-35$ & 74 & 37 & $6-10$ Years & 92 & 46 \\
\hline $36-45$ & 51 & 25,5 & $11-15$ Years & 40 & 20 \\
\hline $45+$ & 26 & 13 & $20+$ Years & 15 & 7,5 \\
\hline Educational level & & & & & \\
\hline Primary school & 8 & 4 & & & \\
\hline High school & 35 & 17,5 & & & \\
\hline $\begin{array}{c}\text { Vocational high } \\
\text { school }\end{array}$ & 106 & 53 & & & \\
\hline Undergraduate & 41 & 20,5 & & & \\
\hline \begin{tabular}{c} 
Graduate \\
\hline
\end{tabular} & 10 & 5 & & & \\
\hline
\end{tabular}

When Table 3 which includes information about the participants is examined, it is seen that $54 \%$ of the participants is female and employees are within the age range of $18-35$ mostly (61,5\%). Again according to the table, educational status of the employees are mostly high school and vocational high school $(70,5 \%)$ levels. Sufficient participation could not be gained for the study in executive positions and participation rate for executives is $11,5 \%$. Finally, sectoral experience of employees is mostly between $1-10$ years.

Table 4: Reliability and Correlation analysis

\begin{tabular}{|c|c|c|c|c|}
\hline \multirow[t]{2}{*}{ Variables } & \multirow[t]{2}{*}{ C. Alpha } & \multicolumn{3}{|c|}{ Correlation } \\
\hline & & 1 & 2 & 3 \\
\hline Career planning (1) & 0,811 & 1,000 & $0,509 * *$ & $-0,481 * *$ \\
\hline Job satisfaction (2) & 0,793 & $0,509 * *$ & 1,000 & $0,415^{* *}$ \\
\hline Gender effect (3) & 0,860 & $0,481 * *$ & $0,415^{* *}$ & 1,000 \\
\hline
\end{tabular}

${ }^{* *} p<0,01$

In Table 4 in which relationships among career planning, job satisfaction and gender effect were analyzed, it is seen that all variables are in a relationship of $p<0,01$ meaning level as a result of Pearson correlation analysis. According to this, as a result of the analysis, there is a positive 0,509 relationship level between career planning and job satisfaction, negative 0,481 relationship level between career planning and gender and positive 0,415 relationship level between job satisfaction and gender. Moreover, it is seen that reliability coefficients pertaining to the variables are within a valid acceptable level. 
Table 5: Confirmatory Factor Analysis

\begin{tabular}{|l|c|c|c|c|c|c|c|}
\hline \multirow{3}{*}{ General } & $\chi^{2} / \mathbf{d f}$ & $\mathbf{P}$ & AGFI & GFI & CFI & FI & RMSEA \\
\cline { 2 - 8 } & 1,719 &, 000 &, 911 &, 928 &, 904 & 860 &, 066 \\
\hline
\end{tabular}

Confirmatory factor analysis was conducted in order to test whether the model is compatible or not in the research. As a result of CFA, it was determined that regression coefficients for some questions in the career planning scale was low and these questions were excluded from the model and accordingly results became meaningful. Analysis variables include general good fit values, it is seen that $\chi 2 / d f$ degree is lower than $3(1,719)$ and $C F I$ and $G F I$ values are above 0,90 . According to these results, it can be said that there is a good fit among variables and mediating variable analysis can be done.

Figure 1: Mediating Effect Model of Gender in Relationship of Career Planning and Job Satisfaction

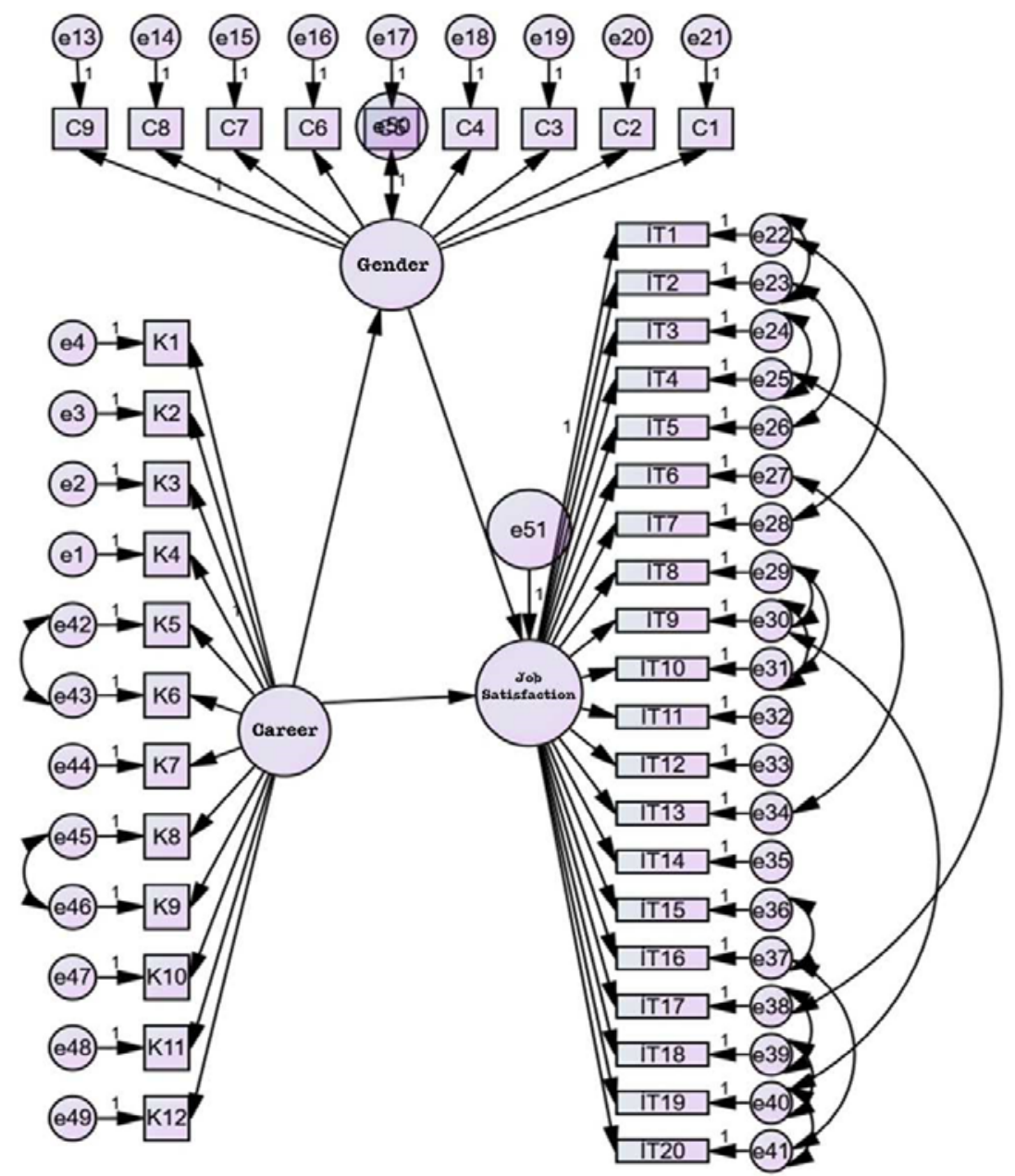

By way of a statistical program, research model was drawn as Figure 1. Because acceptable good fit values could not be reached in the mediator analysis determined for the research, model was exposed to analysis for three times, necessary covariances were drawn on the model and improvement studies were made. In the path analysis, the result of the said mediator was standardized and regression coefficients were given in the Table 3 below and they were interpreted. 
Table 6: Structural Equation Mediating Effect Regression Analysis

\begin{tabular}{|c|c|c|c|c|c|}
\hline & Variables & Estimate* & S.E. & C.R & $\mathbf{P}$ \\
\hline Condition 1 & Job Sat. $\longleftarrow$ Career & 197 & ,226 & 1,053 & ,015 \\
\hline \multirow{3}{*}{ Condition 2} & Gender $\leftarrow$ Career &,- 970 & ,320 & 3,033 & 002 \\
\hline & Job Sat. $\longleftarrow$ Gender & 127 & 152 & 835 & 000 \\
\hline & Job Sat. $\longleftarrow$ Career & 262, & 295, & 1,857 & ,000 \\
\hline
\end{tabular}

*Standardized Regression

Under normal conditions, it is expected for the regression coefficient in the 1st state to decrease in the 2 nd state between career and job satisfaction in order to speak of the mediating effect of gender in the model. However, when it is considered that the relationship of career and gender in the model which is meaningful statistically is negative; it is necessary for the regression coefficient not to decrease but to increase for the existence of the mediating effect. According to Table 3 formed as a result of the path analysis, it is seen that the coefficient which is 0,197 among variables increases to 0,262 by intervention of gender. In this situation, it can be said that career is effective in the rate of $35 \%$ increase rate which is concluded by the intervention of gender in the relationship of career with job satisfaction and other factors have effect in the rate of $65 \%$ on career. Consequently, as a result of the said table it is found that gender has negative mediating effect on relationship of career planning application and job satisfaction, the hypothesis of the research as " $\mathbf{H}_{\mathbf{1}}$ : Gender has a mediating role in the relationship of career development and job satisfaction for female employees" was accepted.

\section{Result}

Despite the fact that it is seen as an expressed situation of the existence of a male dominant working system, career development for females had always been remained unsolved. Eventually, in spite of all kinds of positive developments in international working conditions and human rights, females cannot still gain their deserved positions within working life today. With reference to the researches made in this subject and limitations determined in the theoretical parts of the study, there are several factors causes career barriers for females.

In this study in which mediating role of the gender effect in the relationship of career development and job satisfaction for female employees was examined, first of all literature pertaining to the career barriers were examined and career connection was searched. In the final section of the study, it was tried to determine how career development affected job satisfaction by using structural equation modeling and mediating role of gender was searched. Moreover, the most important section of this study from other researches in the literature is that while career barriers for females were depended on directly to gender in other studies; in this study the rate of the gender effect on the career development was revealed in proportion to other factors.

Almost half of the participants of this study was selected among males and in this manner, it was tried to determine the opinions of career development for both males and females. First of all, a correlation relationship was determined among variables in the research. As a result of the conducted analysis, the existence of a positive relationship between career and job satisfaction was determined, it was seen that there is a negative effect of gender on career and there is a positive relationship again between gender and job satisfaction. In the study of Ersarı et al. (2016) about the relationship of career barriers and organizational culture for female employees in the perspectives of males and females; career barriers of females were evaluated in term of gender in several ways and it was determined that gender was an important factor on career and while males did not care about the barriers for females and on the other hand they felt justified in terms of themselves. Morrison and VonGlinov (1990) concluded that concluded that employing females by 
organizational executive and differences of females in their career developments within organization were perceived as weakness in their study about the career barriers for females. Charles and Davies (2000) stated in their study stated that especially executives discriminated in the career developments of female and male employees in substantially and gave priority to males in terms of promotion and advancement. Blum, Fields and Goodman (1994) stated that the foundation of the career barrier against females was to protect the traditional bureaucratic structures within organizations and seeing talent and career as an important factor of physical power. It is seen that all these studies are in parallel to the research findings.

According to the result of CFA for the compatibility of the model, it can be said that all values are above 0,90 and structural equation modelling mediator analysis can be conducted. Regarding to that fact that the relationship between career and gender relationship is negative in the model, it is expected for regression coefficient to increase in the conducted oath analysis. According to the result of analysis, the coefficient 0,197 among variables had increased to 0,262 by the intervention of gender. In this situation, it can be said that career is effective in the rate of $35 \%$ increase rate which is concluded by the intervention of gender in the relationship of career with job satisfaction and other factors have effect in the rate of $65 \%$ on career.

As can be seen among the result s of the analysis, there is a serious rate of $35 \%$ mediating effect of gender factor between career and job satisfaction for female employees. In this situation, it cannot be said that there is career barrier for females only depending on gender, however it can be said that career development for females did not reach to the desired level in spite of several positive legal arrangement in international areas directed to business life of females and studies of non-governmental organizations today. In this study, the subject of gender in the career developments of females was discussed particularly and it was tried to reveal an awareness for the future studies in order to examine the subject in broader dimensions.

On the other hand, some suggestions can be listed in organizational basis for the solution of the said problem from the answers given to survey questions within the scope of the research.

- To provide necessary inter-organizational support in order to provide self-confidence which is deficit in some female employees

- To make positive discrimination in certain subjects

- To conduct mutual social projects in order to eliminate problems originated from malefemale miscommunication and prejudices towards females.

\section{References}

Acuner, A. Ş. (2019). Kadın Çalışanların Kariyer Geliştirme Sürecinde Karşılaştıkları Sorunlar, Uluslararası Iktisadi ve Idari Incelemeler Dergisi, (23):35-52, ISSN 1307-9832.

Agho, A., Mueller, C. ve Price, J. (1993). Determinants Of Employee Job Satisfaction: An Empirical Test Of A Causal Model. Human Relations, 46 (8), pp.1007-1027.

Akın, A., (2006). Toplumsal Cinsiyet, http://www.gencgazeteciler.org/tcinsiyet.asp(01.01.2019).

Anafarta, N., (2001). Orta Düzey Yöneticilerin Kariyer Planlamasına Bireysel Perspektif, Akdeniz iktisadi ve Idari Bilimler Fakültesi Dergisi (2), ss.1-17.

Anafarta, N., Sarvan, F. ve Yapıcı, N. (2008). Konaklama İşletmelerinde Kadın Yöneticilerin Cam Tavan Algısı: Antalya İlinde Bir Araştırma, Akdeniz Iktisadi ve Idari Bilimler Fakültesi Dergisi (15), ss.111-137.

Aytaç, S. (1999). Çalışma Yaşamında Kadın ve Kariyer, Türkiye'de Kadın İş gücü Seminerleri I-II, T_SK Yayınları, Bursa 28 Nisan 1999, s. 27. 
Aytaç, S. (2001). Çift Kariyerli Esler ve Çalışma Yaşamındaki Yeri, Ezgi Kitabevi Yayınları, Bursa, s. 204.

Aytaç, S., (2005). Çalışma Yaşamında Kariyer, Ezgi Kitabevi Yayınları, Bursa.

Aytaç, S., Sevüktekin, M., Işığıçok Ö., Bayram N., Yıldız S., Eryiğit, K. Y., (2002). Çağdaş Sanayi Merkezlerinde Kadın İşgücünün Konumu: Bursa Örneği. TiSK, Yayın No: 219, s.27- 49.

Bacacı, V., D. (2001). Örgütsel Yasamda Toplumsal Cinsiyet Rolleri, Yönetim ve Organizasyon, (Ed: Salih Güney) Nobel Yayın Dağıtım, Ankara.

Barutçugil, İ., (2004). Stratejik İnsan Kaynakları Yönetimi, İstanbul: Kariyer Yayıncılık.

Blum, T. C., Fields, D. L. ve Goodman, J. S. (1994). Organization-leveldeterminants of women in management. The Academy of Management Journal, 37(2), 241-268.

Charles, N. and Davies, CA. (2000). Cultural stereotypes and gendering of senior management, Theeditorial Board of the Sociological Review, 544- 67.

Ergeneli, A. ve Akçamete, C. (2004). Bankacılıkta Cam Tavan: Kadın ve Erkeklerin Kadın Çalışanlar ve Kadınların Üst Yönetime Yükseltilmelerine Yönelik Tutumları, H.Ü. Iktisadi ve Idari Bilimler Fakültesi Dergisi, 22(2), 2004, s. 87-88.

Ersarı, G. İşcan, Ö. F., ve Naktiyok, A., (2016). Kadın ve Erkek Bakış Açısıyla Kadın Çalışanların Kariyer Engelleri ve Örgüt Kültürü İlişkisi: Akademisyenler Üzerinde Bir Uygulama, lujeas, 1/ 1 35-48.

Gutek, B., Aaron, G., And Tsui, A., (1996). Reaction stop erceived sex discrimination, Human Relations. Vol:49(6), 1996, s.791.

Gül, H., Yalçınoğlu, N., Atlı, Z. C. (2014). Türkiye'de Çalışma Yaşamında Kadının Konumu ve Sorunları. TAF Preventive Medicine Bulletin, 13(2), 169-176.

İnandı, Y. ve Tunç, B. (2012). Kadın Öğretmenlerin Kariyer Engelleri ile İş Doyum Düzeyleri Arasındaki İlişki, Eğitim Bilimleri Araştırmaları Dergisi, Cilt:2, Sayı:2, ss.203-222, Aralık.

Karaca, A. (2007). Kadın Yöneticilerde Kariyer Engelleri: Cam Tavan Sendromu Üzerine Uygulamalı Bir Araştırma, Yüksek Lisans Tezi, Selçuk Üniversitesi, Sosyal Bilimler Enstitüsü, işletme Ana Bilim Dalı, Konya.

Karaca, A. ve İraz, R. (2007). Kadın Yöneticilerde Kariyer Engelleri: Cam Tavan Sendromu Üzerine Uygulamalı Bir Araştırma, Yüksek Lisans Tezi, Selçuk Üniversitesi Sosyal Bilimler Enstitüsü İşletme Ana Bilim Dalı Yönetim ve Organizasyon Bilim Dalı, Konya.

Kılınç, N. Ş. ( 2015). Küresel Eğilimler Çerçevesinde Kadın İstihdamı, Hak-iş Uluslararası Emek ve Toplum Dergisi Cilt: 4, Yıl: 4, Sayı: 9 121-135.

Korkmaz, A. ve Korkut, G. (2012). Türkiye'de Kadının İşücüne Katılımının Belirleyicileri, Süleyman Demirel Üniversitesi İtisadi ve Idari Bilimler Fakültesi Dergisi 17/2, 41-65.

Locke, E. A. (1976). Thenature and causes of jobsatisfaction. In M.D. Dunnette (Ed), Handbook of industrial and organizational psycology (1297-1343). Chicago. RandMcNally.

Lockwood, N. (2004). TheGlassCeiling: Domestic and International Perspectives, HR Magazine, 2004, http://www.findarticles.com (23.01.2019).

Lu, H., A.E. Whilee ve K.L. Barriball (2005). JobSatisfactionAmongNurses: A LiteratureReview, International Journal of Nursing Studies, 42: 211-227.

Morrison, A. M. ve Von Glinov M.A., (1990). Women and Minorities in Management", American Psyehologist, 45, 200-208. 
Önder, N. (2013). Türkiye'de Kadın İşgücünün Görünümü, ÇSGB Çalışma Dünyası Dergisi, 1 /1 , 3561.

Özçelik, K, M. (2017). Çalışma Hayatında Kadının Yeri ve Kariyer Gelişim Engeller, Akademik Sosyal Araştırmalar Dergisi, Yıl: 5, Sayı: 52, Eylül 2017, s. 49-70.

Palaz, S. (2003). "Türkiye'de Cinsiyet Ayrımcılığı Analizinde Neoklasik Yaklaşıma Kurumcu Yaklaşım: Eşitliği Sağlayıcı Politika Önerileri”, Balıkesir Üniversitesi Sosyal Bilimler Enstitüsü Dergisi, 6(9): 87-109.

Sağlam, S., S. (2017). Kadın İstihdamı Raporu: Ulusal ve Uluslararası Sosyal Politikalar, Sosyal Politika ve Planlama 1-18.

Soysal, A. (2010). Türkiye'de Kadın Girişimciler: Engeller ve Fırsatlar Bağlamında Bir Değerlendirme, Ankara Üniversitesi Siyasal Bilgiler Fakültesi Dergisi , Cilt 65 , Sayı 1, ss. 83-114.

Şimşek. Ş, ve Öge, H. S., (2007). Stratejik ve Uluslararası Boyutları ile İnsan Kaynakları Yönetimi. Gazi Kitabevi, Ankara.

Tunçer, P. (2012). Değişen İnsan Kaynakları Yönetimi Anlayışında Kariyer Yönetimi, Ondokuz Mayıs Üniversitesi Eğitim Fakültesi Dergisi, 31(1), 203-233.

Tüz, M. (2003). Kariyer Planlamasında Yeni Yaklaşımlar, U. Ü. Fen-Edebiyat Fakültesi Sosyal Bilimler Dergisi, Yıl: 4, 4 (1)

Uygun, Z. ve Öğüt, A. (2011). Örgüt Kültürünün Kadın Çalışanların Kariyer Gelişimleri Üzerine Etkisi, Selçuk Üniversitesi Sosyal Bilimler Enstitüsü İ̧̧letme Bölümü, Yönetim Organizasyon Bilim Dalı, Yüksek Lisans Tezi, Konya.

Vroom, V. H. (1964). Work and Motivation. New York: Wiley.

Internet Source

http://www.tuik.gov.tr/PreHaberBultenleri.do?id=27699 (Erişim tarihi: 12.02.2019). 
